\title{
Bloomsbury and the University of London.
}

By T. Ll. Humberstone.

BLOOMSBURY, originally Lomosbury, was in
ancient days a retired village, renowned for its wholesome and pleasant air, situated with its manor near the present Bloomsbury Square. The Royal mews, established here, were burnt down in $\mathrm{r}_{537}$, when the hawks and steeds were removed to Charing Cross. Two great houses were in the neighbourhood -Montagu House, which became the British Museum, and Southampton House, afterwards called Bedford House, near the present Russell Square. To the north; was preserved by the ancient landladies, who still cherished the belief that Great Ormonde Street was the hub of the fashionable world.

The British Museum forms the natural centre of the district. Its establishment was due to a man of high scientific attainments, Sir Hans Sloane, a physician, who for a quarter of a century was president of the College of Physicians. He accumulated at his house in Chelsea a vast and varied collection of books and manuscripts, objects of natural history, and works of

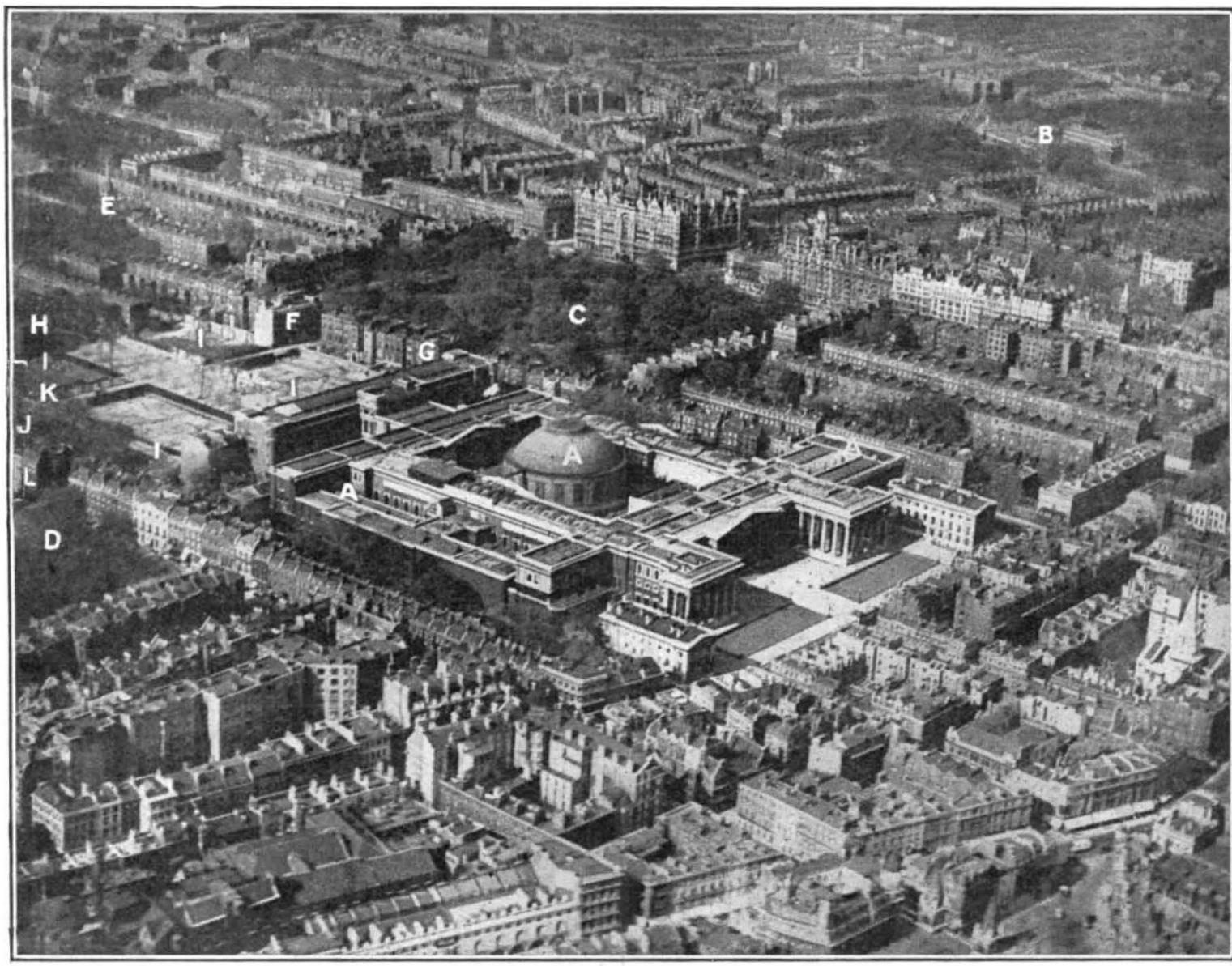

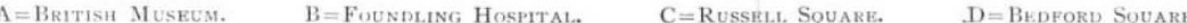

Photo by Central Aenophoto C. $\mathrm{F}=$ InstitutK of Cheshistry. $\mathrm{i}=$ Royal. Institute of Public $\mathrm{H}$ $J=$ Site for INstitute of Public Health.

$\mathrm{K}=$ UNIVERSITY OF LONDON UNION. $\mathrm{L}=$ CAVENDISH'S HoUSE.

stretching towards Hampstead and Highgate, was open country with irregular patches, frequented by duellists, and the scene of robbery, murder, and every form of depravity.

Russell Square was built at the beginning of the nineteenth century, and became the resort of "gentlemen of the long robe." In those days, or somewhat earlier, Great Ormonde Street was a centre of fashion, but in course of time the district lost caste, and it was accounted a mark of high breeding not to know the locality. Croker inquired in the House of Commons, "Where is Russell Square?" It is recorded, however, that the dignity of this once patrician quarter of London art, which he directed by his will should be offered to the nation on favourable terms. After his death, in I753, an Act of Parliament was passed approving the acquisition of the collection, together with the Harleian Library of Manuscripts and the Cottonian Library; and to house the collections the Government purchased Montagu House, raising for this purpose, by means of a lottery, the sum of $100,000 l$., of which $20,000 l$. was used for the purchase of the Sloane Collection. The museum was opened in $\mathbf{I 7 5 9}$, and ever since has been available for "studious and curious persons," to quote the official regulations. In its gardens were encamped, in 1780 , the troops who quelled the Gordon Riots.

NO. 2752 , VOL. I IO] 
George IV.'s Library was afterwards purchased, the Quarterly Review spitefully remarking that women's looks were the only books His Majesty required. The present building was designed by Sir Robert Smirke. It was commenced in 1846 and cost $800,000 l$., an amount which is worth remembering in view of the fanciful estimates of the cost of housing the University of London on the adjoining site. The dome of the library is said to be the largest in the world, with the exception of the Pantheon at Rome. The north extension is a recent addition of great architectural dignity.

The next most important building in Bloomsbury is undoubtedly University College in Gower Street, founded in 1826 to afford "literary and scientific education at a moderate expense." Tom Campbell, the poet, and Lord Brougham share the credit for its foundation. Campbell, in his letter to the Times, suggested that a number of the "middling gentry" in London would be prepared to pay 5 ol. to furnish the inside of their skulls, that being the amount willingly paid for a full-bottomed periwig for external adornment. The College was nicknamed Brougham's "patent omnibus" as a play on the motto Patens omnibus Scientia. From the first, however, the ideals of the College were high and comprehensive. "May God," prayed H.R.H. the Duke of Sussex in laying the foundation stone on April 30, I827-it should be noted that the centenary of this auspicious event is rapidly approaching-" bless the undertaking which we have so happily commenced, and make it prosper for the honour, happiness, and glory, not only of the metropolis, but of the whole country." This odour of sanctity was short-lived, for the Church party stigmatised the institution as the "Godless College," and established King's College in the Strand as an antidete. Nevertheless, the Duke's prayer has been answered; the bare fact of the inclusion of Lister's name in the list of distinguished alumni would be sufficient proof. After the ceremony the company dined together at the Freemasons' Tavern, thus establishing an early tradition of good-fellowship. The beautiful buildings, with the characteristic portico and graceful cupola, were designed by William Wilkins, the architect of the National Gallery.

The College is not included in the photograph, but to the north of the British Museum are to be seen the four plots recently purchased by the Government for the new headquarters of the University of London. The whole of Torrington Square and parts of Russell and Woburn Squares also belong to the University site of II $\frac{1}{2}$ acres, to which it is proposed to move King's College also in the fulness of time. 'This is not the occasion to attempt even the briefest summary of the controversy which has raged round this question during the past eleven years. One point is, however, pertinent, as it is illustrated by the photograph. It has been charged against the site that its division into four plots is a great disadvantage. Could it not be urged with equal force that this is one of its greatest advantages? The four plots will permit of the construction of a group of well-lighted and ventilated buildings, with numerous entrances and appropriate purposes. The alternative of a mammoth single building would inevitably suffer from defects of lighting and ventilation, and would cause endless annoyance through the waste of time involved in pacing long corridors. The modern civic university must be, literally and figuratively, on the street rather than in some secluded grove. As will be seen, one of the plots is occupied by some wooden buildings, which have been acquired by the University Union Society from the Young Men's Christian Association as a temporary home. Immediately to the north is the University Institute of Historical Research, established last year for the benefit of students pursuing their investigations at the British Museum, the Public Record Office, and other archives. There they will come " to discuss their problems' and results, and to receive that oral guidance for which they are properly debarred in libraries and manuscript departments." The Institute includes departments for English and Colonial history, naval and military history, the history of London, and of various foreign countries, and palæography. The plan is admittedly " opportunist rather than ideal," but the Institute may serve as a model and forerunner of numerous University Institutes. for special studies. Between the wooden buildings and Gower Street is the site of the new Institute of Public Health to be established by the Rockefeller Foundation.

Bloomsbury has many interesting associations, as the plaques fixed to its houses testify. These are mostly literary or artistic, but occasionally scientific. At the Bedford Square end of Gower Street is the house where Cavendish, the chemist and philosopher, lived for some years. The house became packed with books and apparatus, and another in Dean Street, Soho, was taken as a library. When Cavendish wanted a book he signed a formal receipt. Enormously wealthy, he made no use of his money. His daily fare consisted of legs of mutton; and it is said that when his servant informed him that the one leg of mutton in the house would not be sufficient for the company, Cavendish instructed him to get another. Such simple direct answers to difficult questions are the acid test of greatness. We read also that Cavendish gave to Humphry Davy some bits of platinum for his experiments, and visited him to see the results of his experiments on the decomposition of the alkalis. He died in $\mathrm{x} 8 \mathrm{I}$.

While the Bloomsbury landlady, to whom respectful tribute has already been paid, remains extant, the district, as a whole, is rapidly changing in character. Russell Square and Bedford Square and the adjoining streets provide accommodation for a large number of learned and other societies of an academic character, and for several teaching institutions connected with the University of London, in addition to those already mentioned. The district is favoured by foreign consulates, the legal, architectural, and other professions, and by business concerns for administrative purposes. It certainly offers many attractions in its "wholesome and pleasant air," its nearness to the great railway termini, its dignity and traditions, its faint historical aroma, its spacious squares and wide streets. As London grows, a process which continues without rest or abatement, the importance of its central areas must be accentuated for all public and private purposes involving the visitation or meeting together of people from the environs of the city. Therefore, whatever its detractors may allege, the future of Bloomsbury is assured. 